\title{
Views of Religious Leaders on Radicalism in Palu
}

\author{
City \\ Rus'an ${ }^{1}$, H. Juraid Abdul Latief ${ }^{2}$, Muhammad Khairil ${ }^{3}$, Hasan Muhamad $^{4}$ \\ ${ }^{I}$ Social Science Study Program Postgraduate Doctoral Program, Tadulako University, Palu-Central Sulawesi, Indonesia \\ ${ }^{2}$ Faculty of Teacher Training and Education, Tadulako University, Palu-Central Sulawesi, Indonesia \\ ${ }^{3,4}$ Faculty of Social and Political Sciences, Tadulako University, Palu-Central Sulawesi, Indonesia
}

\begin{abstract}
The view of Religious Figures towards Radicalism in Palu City, Central Sulawesi. This study aims to: 1) find out the views of religious figures in Palu City about radicalism in the context of thoughts or ideas, 2) to find out the views of religious figures in Palu City about radicalism in actions and movements, 3) To find out the strategies in overcoming radicalism. This research employed a qualitative method with an inductive approach. The research informants consist of interfaith leaders in Palu City. Data were collected through observation, in-depth interviews, and document studies. The study results show that the views of religious figures in Palu City on radicalism in the context of thoughts or ideas are not disputed and not to be concerned because every religious adherent wants to return to the basis of his religious purity. Therefore, the truth claim, which is considered one of the radical characteristics, is wrong. Religious adherents must believe in the fact of their religion and must believe that anything Contrary to their religion is wrong. Believing in the truth of religion is a condition of faith in every adherent. Thus it should not be a concern as long as it is not followed by violence. The view of religious figures in Palu City towards radicalism in the context of actions and movements violates all religious values. No religion justifies violent actions. The strategies in anticipating and reducing the growth of radicalism, namely maintaining and reviving the culture of local wisdom and building interfaith communication through the Religious Communication Forum (FKUB).
\end{abstract}

Keywords: Radicalism, Religious Figure

\section{INTRODUCTION}

$\mathrm{T}$ he issues of radicalism are currently back into a hot and interesting discussion. Radicalism is seen as a serious problem for many people. Since the WTC tragedy, September 11,2001 , issues of radicalism and terrorism have surfaced in the mass media, published in books and academic journals. However, some assumptions are that the categorization is a Western fabrication to divide Muslims and prevent Muslims from advancing and uniting. Therefore, it is not strange that when the Bali Bombings I in 2002 and Bali Bombing II in 2005, among Islamic leaders who stated that the terrorists were only "engineered" by the West to damage the image of Islam so that they were always associated with terrorism, we can say that radicalism and terrorism not purely Western creations, but indeed real facts because there are those who believe, embrace, and develop it from among the Muslims themselves. (Ahmad Fuad Fanani, 2013:4). Therefore, the term radicalism can be seen as intrinsically related to the concept of political and social change at various levels. (Added Dawisha: 1986: 14).

In line with this, Muhammad Khairil in Meuleman stated that the fall of the Suharto regime in May 1998, followed by a political and economic crisis, was a stimulus for the Islamic radicalism movement which had just proclaimed its existence in general. The new groups that stood out were Laskar Jihad, the Islamic Defenders Front, and the Indonesian Mujahideen Forces. (Khairil, 2019: 29)

On the other hand, there is America's double standard in the September 112001 incident, namely the politics of attacking Iraq on the one hand and allowing Israel to attack Palestine. This sparked anti-American sentiment and resistance to Western hegemony in the form of acts of terrorism, such as on March 11, 2004, the bombing of a train station in Madrid, Spain, by Moroccan Islamic Fighters, killing 191 people. Similarly, on July 7, 2005, there was another bombing at three subways and a bus in the UK by the al-Qaeda network. (Mubarak, 2007).

In connection with this, Sidney Jones (2013) revealed that the threat of terrorism and radicalism in Indonesia is real, but only a radical Muslim minority, and even fewer who like to use violence. (Fanani, 2013). In contrast to Syafi'i Ma'arif (2013: 242) that since the $9 / 11 / 2001$ tragedy, humanity has been shocked by the problem of terrorism with thousands of victims. In line with that, Din Syamsuddin, looking at the phenomenon of radicalism, stated that there is a political enemy behind the constant accusations of radical Muslims. Din Syamsuddin saw the accusation as unfounded due to the constant radical accusations against Muslims. If the Muslims were radical or adherents of radicalism, there would be no Pancasila State. Precisely because of the high statesmanship and tolerance of Islamic leaders,http://share. babe.news/al/jFvNFNRcvR 6/5/2021

Emna Laesa (2014), sees that basically, any religion tends to make truth claims (claiming to be the most correct) because religion is a belief value that its adherents must firmly hold. However, the truth claims attitude will have a positive value if it is only oriented inward (intrinsic orientation) in its appreciation and application, not to the outside (extrinsic orientation), which causes negative prejudice and conflict. Islamuna Volume 1 Number 1 June 2014. 
Achmad Jainuri (2016: 5) explained that conceptually there are two meanings of radicalism, namely: 1) radicalism in the context of thoughts or ideas, namely thinking based on an understanding and belief in a statement, value, and view that is owned by everyone and judging as the most correct, and conversely looking at the disapproving is wrong. It is difficult to interact with closed characteristics except with their group; 2) radicalism in the movement is a non-compromising approach to social, political and economic issues marked by very high dissatisfaction with the status quo and a desire for rapid growth and extreme change. Based on the phenomenon of radicalism as a thought or as a movement in the form of acts of terror and acts of violence,

This research is corroborated by several previous studies different from the research conducted by researchers, including:(1) Mubarak (2013), whose title is From the Spirit of Islam to a Radical Attitude: Religious Thoughts and Behaviors of Students of UIN Syarif Hidayatulah Jakarta. The research findings are, the factors that support the development of radical religious movements in universities are closely related to changes in the socio-political dimension which ultimately have implications for campus life; (2) Zuly Qadir (2014) in his research "Islamic Radicalism in Yogyakarta" concludes, the development of radicalism thrives even though it has a slightly different character from other areas. The characteristics of radicalism on the Yogyakarta campus do not use physical violence methods but use ways of strengthening ideas aimed at resistance; (3) Rini Marlina (2019) in her research on Religious Radicalism in the View of Islamic Religious Figures in Banda Aceh City. The results of the study show that the teachings and movements of radicalism are understood by Islamic religious leaders in Banda Aceh City as an understanding that wants to make a change both politically and socially by means of violence, which is contrary to Islamic values; (3) Zoid Ramadlan (2020) in his research on the Discourse of the Radicalism Movement in Islamic Organizations (Study of Hermeneutics in Muhammadiyah and Nahdlatul Ulama Islamic Organizations on the Basic State, Jihad, and Tolerance. that the teachings and movements of radicalism are understood by the Islamic religious leaders of Banda Aceh City as an understanding that wants to make a change both politically and socially by means of violence, which is contrary to Islamic values; (3) Zoid Ramadlan (2020) in his research on the Discourse of the Radicalism Movement in Islamic Organizations (Study of Hermeneutics in Muhammadiyah and Nahdlatul Ulama Islamic Organizations on the Basic State, Jihad, and Tolerance. that the teachings and movements of radicalism are understood by the Islamic religious leaders of Banda Aceh City as an understanding that wants to make a change both politically and socially by means of violence, which is contrary to Islamic values; (3) Zoid Ramadlan (2020) in his research on the Discourse of the Radicalism Movement in Islamic Organizations (Study of Hermeneutics in Muhammadiyah and Nahdlatul Ulama Islamic Organizations on the Basic State, Jihad, and Tolerance.
Based on the phenomenon of the radicalism movement, the justification of Islam as a radical group, as well as support from the research results, it is considered necessary a research study that examines "Radicalism in the view of religious leaders" (cross-religious) and "how to overcome/stem the seeds of radicalism in Palu City".

\section{RESEARCH METHODS}

This research is field research, which uses qualitative methods. Denzin and Lincoln Satori (2011) define qualitative research as research that uses a natural setting to interpret the phenomena that occur and is carried out using existing methods. As a constructivist-interpretative method, a qualitative model. The research location is Palu City, Central Sulawesi Province, as a place of residence for religious leaders as subjects in this study. Burhan (2008) sees a unit of analysis consisting of two levels, both as a subject and as a subject, an actor of reality.

Informants were selected purposively based on experience, knowledge, interests, status, social and institutional influences. The data source in this study is primary data obtained from the field with secondary data in the form of documents and literature. Field data collection with interview techniques using interview guidelines on several predetermined informants.

Data analysis was carried out qualitatively through a series of mutually supportive and continuous processes before, during, and after field data collection. This process includes data reduction, data categorization, interpretation (interpretation) of data meaning and symbolic interpretive analysis. (Endraswara, 2006)

\section{RESULTS AND DISCUSSION}

Views of Religious Leaders on Radicalism in the Context of Thought

The view of religious leaders against radicalism in the form of thoughts or ideas is natural and should exist in all religions. It is not a problem between religious communities as long as intolerance and acts of violence do not accompany it. According to ZA, as an Islamic figure from the Nahdlatul Ulama Organization and the Chairperson of the Palu City MUI, he stated that "if you go back to the definition of radical. in the philosophical approach, extreme means people who think to their roots, this is taken from the word radix, which means root. So radicalism is the understanding of people who believe to their hearts, it is a good way of thinking, so that in philosophy if we want to find the ultimate truth, we must think radically.

In seeing something, it is not only on the surface but also analyzes its roots. That is what is meant by a radical approach to philosophy. If some practice their religious teachings well according to their understanding, for example, in Islam some practice veils, grow beards and wear cingkrang pants as long as they do not commit acts of violence and are tolerant of all religions, that is a good and positive thing. 
In line with this, Alkhairat said that 'radicals in practising religion must adhere to the basic teachings of Islam and if they are in the outside environment, do not blame people who disagree with the principles. The above explanation is supported by the views of several national figures such as Syafi'i Ma'arif (2013: 242), who strongly reject the labelling of radicalism or terrorism aimed at Islam. On the other hand, Catholic figures in Palu City think that 'radicalism involves thinking to its roots. This means that if it is associated with religion, actually every religious adherent wants to return to his original, pure teachings'.

Views of Religious Leaders on Radicalism in the Context of Action

The views of religious leaders in responding to radicalism in actions and movements explain 'radicalism that acts anarchically needs to be watched out for'. The phenomenon of destructive radicalism is a dangerous form of training because this movement may lead to acts of treason, massive demonstrations, or revolutionary activities and can even turn into terrorist acts. Violence can occur if the way of understanding religion is wrong. It may be that the way of understanding religion is incorrect or incomplete because it does not understand religion to its roots, so a radical group is born. Therefore, religious leaders agree that issues of violence, radicalism, terrorism are associated with particular religions.

This statement is in line with Muhammad Khairil (2016: 73), which states that the fact that is quite ironic is when reporting on terrorism in the mass media is always identified with Islamic organizational figures and their organizational activities so as to corner Muslims and form public opinion in the midst of society, especially the public. non-Muslims and who do not fully understand the nature of Islam. The assumption that Islam is a terrorist and a terrorist is Islam is in complete contradiction with the conception of Islam as a religion of grace for all the worlds.

Various accusations, slander, and speculations that are often premature are sometimes difficult to justify the truth, validity, and validity, whether developed by the United States or developed in Indonesia, lead to or are identical to radical or fundamental Islamic movements.

Based on reviews of religious leaders in Palu City regarding the assumption and justification that religion is a trigger for radicalism and terrorism is a very wrong thing and tends to lead to slander, in his statement he states that anyone who thinks that religion is a trigger for radicalism and terrorism is a statement that corners all religions, because the essence of the basic teachings of religion is universally oriented to human values, no religion allows committing acts of violence, let alone killing. All religions carry the teachings of humanity. Religion always teaches peace, harmony, and tolerance, where religion teaches coexistence among people of different religions. Such religious teachings, according to religious leaders, are the substance and principal in religious teachings. Therefore anyone who commits acts of violence, then it is contrary to religious values. The religion of Islam came to be a mercy to the whole world; Christianity came to spread love; Hinduism comes with the teachings of Ahimsa in Panca Yama Brata, which means that it is not allowed to do violence and kill; Buddhism went with the teachings of the Kalama Sutta, the Buddha stated that; Hinduism comes with the teachings of Ahimsa in Panca Yama Brata which means that it is not allowed to do violence and kill; Buddhism came with the teachings of the Kalama Sutta, the Buddha stated that; Hinduism comes with the teachings of Ahimsa in Panca Yama Brata which means that it is not allowed to do violence and kill; Buddhism came with the teachings of the Kalama Sutta, the Buddha stated that;three roots of evil one of which is hatred and violence.

\section{Strategies in Overcoming Radicalism Building Sintuvu Local Karifan Culture}

The culture of gotong royong is a form of cooperation to achieve certain goals with the principle of reciprocity or reciprocity that creates social order in society. Gotong royong can be realized in a spontaneous form, based on self-interest or because it fulfils social obligations. The form of mutual cooperation varies according to the fields and social activities carried out. The people of the city of Palu are known for their cooperation system, which has long been known and even lives and develops under the term Sintuvu (Kaili language). According to J. Kruyut, the term Sintuvu shows the meaning of living together based on the similarity of life. This is based on a pattern of shared life that causes people to walk together, take the same path, show themselves with feelings.

Sintuvucontains has many meanings that have long-lived, grown, and developed in the Palu area: 1) Sintuvu is a mutual agreement to carry out an activity together. This understanding implicitly implies the existence of deliberation (libu) in a social institution that produces joint decisions. 2) Sintuvu is an activity of dota ntodea (the will of the people) or dota couplesgani (the will together) to do some work. 3) Sintuvu is a cooperative activity of mutual help driven by a sense of kinship, a sense of togetherness, and a life of fellowship in one community, for the benefit of a person, family, relatives, and society in general. 4) Sintuvu is an activity of helping to do an activity in various fields and fields of life that is considered excellent and commendable which requires cooperation or the help of others. From the several definitions stated above, it can be concluded that the concept of sintuvu has the same meaning as gotong royong. Sintuvu culture offers a universal family value, namely kinship that is not limited by genealogical factors alone but kinship in a broader sense, namely the Indonesian nation. Families that are only limited by genealogical principles in the nation's society can lead to an attitude of primordialism. Therefore,

Sintuvu values that can build empathy in society are the spirit of sharing and solidarity. The spirit of sharing (nadamba rara nombadekei) or generosity (nanondo) in Sintuvu culture is a wisdom that is relevant to the orientation of the Indonesian people's life values, namely achieving inner and outer 
happiness. The spirit of sharing is not measured by material values but is considered kindness and a form of brotherhood to correlate with humanist, social, and religious values. The spirit of sharing in the Kaili community is usually shown in traditional ceremonies, life cycle ceremonies, and other activists who need the help of others. Dwi Septiwiharti, (2021: 281)

In the context of gotong royong (sintuvu) culture concerning preventing radicalism, that gotong royong (sintuvu) gives birth to the values of collaboration or cooperation, strengthening communication, positive interdependence, creating a sense of caring for others, always being responsive to the surrounding environment.

The people of Palu City, in particular, have the potential to revive the culture of gotong-royong (sintuvu), namely the ability to carry out activities together voluntarily so that the activities carried out can run smoothly, easily, and lightly. This ability is based on fairness, respect for fellow human beings, reliability, responsibility, caring, compassion, and generosity. This capability is also based on the democratic principle of Pancasila. The ability of gotong royong (sintuvu) in the community can make it collaborate with other residents in the context of thinking about and proactively seeking fellow citizens to strive for the welfare and happiness of the people in their community. People also realize that their success cannot be achieved without the role of others.

So the community's culture of cooperation (sintuvu) shows that it cares about its environment and is willing to share with other community members to lighten each other's burdens and produce a better quality of life. With a culture of cooperation, people can become democratic citizens, actively involved in society in advancing the nation's democracy. All these cultural values of gotong royong (sintuvu) can prevent the growth of radicalism both individually and in groups.

Sintuvu as local wisdom that is in harmony with the Pancasila State Basis illustrates that the Kaili people have always had a culture of cooperation and assistance in its various dimensions in the form of local wisdom live in peace, unity, harmony, and harmony.

\section{Building Communication of Interfaith Leaders.}

The Central Sulawesi Religious Harmony Forum (FKUB) isa community organization based on glorifying religious values to create tolerance between religious communities, especially in Palu. FKUB has a very strategic role and function in building communication and dialogue between religions to reduce the growth of radicalism in Palu City. Building interreligious communication is one of the main assets for the management of the Religious Harmony Forum (FKUB) to maintain inter-religious harmony in the Province of Central Sulawesi and especially in particular Palu City.

This institution maximizes its role in building dialogue and communication through interfaith leaders, from representatives of several religions including Islam,
Protestantism, Catholicism, Hinduism, Buddhism, and Confucianism so that harmonious relations between religions are established and mutually open.

\section{Tonda Tulusi's Local Wisdom as Suppressor of Radicalism}

The system built in culture is one of the efforts to overcome conflicts in the Kaili community to realise peace and harmony. In addition to the government and religious figures, traditional leaders also have an important role in creating peace in the land of Kaili as part of the tonda sincerei system. Therefore, the customary council in the Kaili community is seen as relevant and contributes to the preservation of Kaili culture. The customary council is an inseparable part of the cultural inheritance process in ensuring the validity of customary norms in the Kaili community, the values of togetherness in the Sintuvu culture are one source of values that have urgency in the application of social norms, among others, implemented in the Kaili customary law called atura nuada.

Related to the handling of radicalism with local wisdom be sincere. Religious leaders and traditional leaders play a role in dealing with the emergence of radicalism, taking preventive actions namely to prevent deterrence, or before they are already imbued with the notion of radicalism, then there is an effort to invite and attract them to learn about national insight, outreach actions, and carry out useful activities. Furthermore, repressive action is an act of social control that is carried out after a violation or bad event occurs. That is, actions taken after or after the event occurred. Finally, related to the handling in curbing radicalism, when acts of radicalism have begun to commit acts of violence. From that explanation, he explained, that "the philosophy of life of the Kaili people contained in the value of Tonda Tarusi is a form of local wisdom values and can be used as social capital to preventtheseedsofradicalismandterrorism.

\section{CONCLUSION}

Based on the previous description, it can be concluded as follows:

1. There are no differences in the views of religious leaders in Palu City in viewing radicalism in the context of thoughts or ideas;

2. The views of religious leaders in Palu City towards radicalism in the context of actions and movements violate all basic religious values because no religion justifies and tolerates acts of violence.

3. Strategies in anticipating and reducing the growth of radicalism through strengthening local wisdom and building interfaith communication.

\section{SUGGESTION}

Research suggests, anticipating the growth of seeds of radicalism in the form of action/action, it is deemed necessary, as follows: 
1. Strengthening local wisdom such as Sintuvu, Tonda Talusi, Libu is used as the basis for solving problems, mainly stemming action radicalism both from within and from outside the community;

2. Maximizing the institutional role of FKUB, especially dialogue and intensive communication between religious leaders, to create openness and harmonization of relations, create a joint determination to prevent and overcome the growth of seeds of radicalism and terrorism in Palu City, in particular, and Central Sulawesi in general.

\section{REFERENCES}

[1] Burhan, B. (2008). Metodologi Penelitian Kualitatif: Aktualisasi Metodologis ke Arah Ragam Varian Kontemporer. Rajawali Pers.

[2] Din Syamsuddin, 2021 Tribunnews.com. Forum Pesantren Alumni Gontor (FPAG) Nilai Tuduhan terhadap Din Syamsuddin adalah Pembohongan

Publik.Tribunnews.com.http://m.tribunnews.com/amp/nasional/20 21/02/14/forum-pesantren-alumni-gontor-nilai-tudihanterhadapan-din-syamsuddin-adalah-pembodohan-publik Februari 2021)

[3] Endraswara, Suwardi. 2006. Metodologi Penelitian Kebudayaan.(Yogyakarta: Gajah Mada University Press).

[4] Fuad, Fanani Ahmad. Fenomena Radikalisme di Kalangan Kaum
Muda, Jurnal Maarif, Arus pemikiran Islam dan Sosial. Volume 8 Nomor 1 Juli 2013

[5] Jainuri, A. 2016. Radikalisme dan Terorisme: Akar Ideologi dan Tuntutan Aksi. Ontrans Publishing.

[6] Jainuri, A. (2016). Radikalisme dan Terorisme: Akar Ideologi dan Tuntutan Aksi. Ontrans Publishing.

[7] Khairil, M. 2019. Resolusi Komunikasi Tindak Penanganan Terorisme. Simbiosa Rekatama Media

[8] Mubarak, M. Z. 2013. Dari Semangat Islam Menuju Sikap Radikal: Pemikiran dan Perilaku Keberagamaan Mahasiswa UIN Syarif Hidayatullah Jakarta. Jurnal Maarif, Arus pemikiran Islam dan Sosial. Volume 8 Nomor 1 Juli 2013

[9] Maarif, Syafii Ahmad. Agama, Terorisme, dan Peran Negara, Jurnal Maarif, Arus Pemikiran Islam dan Sosial. Volume 8 Nomor 1 Juli 2013

[10] Marlina, Rini. 2019. Radikalisme Agama dalam Pandangan Tokoh Agama Islam di Kota Banda Aceh, Skripsi. Banda Aceh. Universitas Islam Negeri Ar-Raniry Darussalam Banda Aceh.

[11] Qodir, Zuly. (2014). Radikalisme Agama di Indonesia. Pustaka Pelajar

[12] Qodir, Zuly. 2013. Perspektif Sosiologi tentang Radikalisasi Agama Kaum Muda. Jurnal Maarif "Arus Pemikiran Islam dan Sosial”. Vol. 8 No. 1 Juli 2013

[13] Romadlan, Zoid. 2020. Diskursus Gerakan Radikalisme dalam Organisasi Islam (Studi Hermeneutika pada Organisasi Islam MuhammadiyahdanNahdlatulUlamatentangDasarNegara,Jihad,dan Toleransi). Jakarta. Diseratsi Program Pascasarjana Universitas Indonesia. 2020 